\title{
Radiodiagnostics in the Follow-Up of Breast Cancer Patients
}

\author{
Max Dieterich Bernd Gerber \\ Universitäts-Frauenklinik am Klinikum Südstadt, Rostock, Germany
}

Key Words

Breast cancer: recurrence, metastasis, follow-up .

Bone scan, hot spot $\cdot$ X-ray, chest

\section{Summary}

Background: New treatment options have revived discussions about the role of perioperative screening and intensive follow-up in early breast cancer (BC), with the role of radiological staging in follow-up for $B C$ patients being a controversial subject. The aim of this literature review is to determine the importance of X-ray in BC patients. Material and Methods: Literature research was performed in Pubmed. A total of 173 abstracts were reviewed, and 27 original articles and 1 Cochrane Database System Review were evaluated. Results: Perioperative staging and routine staging for follow-up in asymptomatic patients has no benefit for disease free survival and overall survival, and is associated with a high false positive rate. Hot spots in bone scans are mostly of benign origin and require further X-ray clarification. Conclusion: Due to the currently unproven benefit and missing therapeutically consequences, X-ray can not be recommended for perioperative screening or regular followup in asymptomatic BC patients.

\section{Introduction}

Currently, there are new public discussions regarding perioperative screening and intensive follow-up of asymptomatic breast cancer (BC) survivors [1,2]. This is explained by newer

\author{
Schlüsselwörter \\ Brustkrebs: Rezidiv, Metastasen, Nachsorge · \\ Skelettszintigraphie, Hot Spot · Thorax-Röntgen
}

\section{Zusammenfassung}

Hintergrund: Bedingt durch neue Therapieoptionen gibt es derzeit erneut Diskussionen über die Rolle des perioperativen Screenings und regelmäßiger Nachsorgeuntersuchungen bei Brustkrebspatientinnen. Hierbei wird die Rolle von Röntgenuntersuchungen kontrovers diskutiert. Ziel dieser Übersichtsarbeit ist es, den Stellenwert des Röntgen von Brustkrebspatienten perioperativ und in der Nachsorge zu bestimmen. Material und Methoden: Eine Literaturrecherche wurde in Pubmed vorgenommen. Insgesamt wurden 173 Abstracts begutachtet und 27 Orginalarbeiten sowie ein Cochrane Database System Review ausgewertet. Ergebnisse: Röntgenuntersuchungen zum perioperativen Staging sowie in der routinemäßigen Nachsorge asymptomatischer Patienten ergeben keinen Benefit für das erkrankungsfreie Intervall und das Gesamtüberleben, und sind mit einer hohen Falsch-Positiv-Rate verbunden. "Hot Spots" in der Skelettszintigraphie sind meist benigner Genese und bedürfen häufig weitererführender radiologischer Abklärung ohne Benefit für das Outcome. Schlussfolgerung: Aufgrund des (bisher) nicht nachgewiesenen Benefits und fehlender therapeutischer Konsequenzen sind Röntgenuntersuchungen weder perioperativ noch in der Nachsorge von asymptomatischen Patientinnen indiziert.

treatment options. It is supposed that an early detection and earlier treatment of recurrence would improve the outcome, especially the overall survival (OAS). For the detection of clinically occult metastases, different imaging methods are available, however, most of them are very expensive and not

\begin{tabular}{ll}
\hline KARGER & @ 2007 S. Karger GmbH, Freiburg \\
$\begin{array}{l}\text { Fax +49 761 45207 14 } \\
\begin{array}{l}\text { E-mail Information@Karger.de } \\
\text { www.karger.com }\end{array}\end{array}$ & $\begin{array}{l}\text { Accessible online at: } \\
\text { www.karger.com/brc }\end{array}$
\end{tabular}

Dr. med. Max Dieterich

Universitäts-Frauenklinik am Klinikum Südstad

Südring 81, 18059 Rostock, Germany

Tel. +49 381440145-00, Fax -99

E-mail max.dieterich@uni-rostock.de 
Table 1. Perioperative staging in breast cancer patients without clinical signs of tumor spread; bone and pulmonary metastases detected by chest X-ray only

\begin{tabular}{|c|c|c|c|c|c|c|}
\hline $\begin{array}{l}\text { Author, year } \\
\text { [reference] }\end{array}$ & Patients, $\mathrm{n}$ & $\begin{array}{l}\text { Patient } \\
\text { characteristics }\end{array}$ & $\begin{array}{l}\text { Overall distant } \\
\text { metastasis, \% }\end{array}$ & $\begin{array}{l}\text { Bone metas- } \\
\text { tasis, \% }\end{array}$ & $\begin{array}{l}\text { Pulmonary } \\
\text { metastasis, \% }\end{array}$ & Conclusion \\
\hline Abuzallouf, 2007 [34] & 785 & $\begin{array}{c}\text { retrospective } \\
\text { stage }^{\mathrm{a}} \mathrm{I}+\mathrm{II} \\
\text { stage III }\end{array}$ & $\begin{array}{r}0.7 \\
16.2\end{array}$ & 3.7 & 0.8 & no routine perioperative staging \\
\hline Puglisi, 2005 [7] & 516 & $\begin{array}{l}\text { prospective } \\
\text { stage I-III } \\
\text { stage I+II } \\
\text { stage III }\end{array}$ & 6.4 & $\begin{array}{r}6.3 \\
14.0\end{array}$ & $\begin{array}{l}0.9 \\
7.2\end{array}$ & staging only in stage III patients \\
\hline Ravaioli, 2002 [5] & 1,218 & $\begin{array}{l}\text { retrospective } \\
\text { pT1-4, N0/1/2 }\end{array}$ & 3.8 & 3.1 & 0.7 & $\begin{array}{l}\text { staging only in high risk patients } \\
(\mathrm{T} 3 \text { or } \mathrm{N}>3+\text { ) }\end{array}$ \\
\hline Myers, 2001 [6] & $\begin{array}{l}1,307 \text { (bone) / } \\
3,884 \\
\text { (pulmonary) }\end{array}$ & $\begin{array}{l}\text { retrospective } \\
\text { stage I } \\
\text { stage I } \\
\text { stage III }\end{array}$ & $\begin{array}{l}- \\
- \\
-\end{array}$ & $\begin{array}{r}6.8 \\
8.8 \\
24.5\end{array}$ & $\begin{array}{l}0.1 \\
0.2 \\
1.7\end{array}$ & $\begin{array}{l}\text { staging only in high risk patients } \\
(\mathrm{T} 3 \text { or } \mathrm{N}>3+)\end{array}$ \\
\hline Gerber, 2003 [11] & 1,076 & $\begin{array}{l}\text { retrospective } \\
\text { T1-4, N1-3 } \\
\text { pT1c } \\
\text { pT 2 } \\
\text { pT 3 } \\
\text { N0 } \\
\text { N1-3+ } \\
\text { N } \geq 4+\end{array}$ & $\begin{array}{r}2.8 \\
1.6 \\
3.0 \\
15.1 \\
1.9 \\
4.0 \\
8.5\end{array}$ & $\begin{array}{l}0.9 \\
0.9\end{array}$ & $\begin{array}{l}1.8 \\
0.9 \\
0.9\end{array}$ & $\begin{array}{l}\text { perioperative screening is not } \\
\text { warranted in T1-2 and / or } \\
\mathrm{N} 0-3+\text {; false positive findings }\end{array}$ \\
\hline Ravaioli, 1998 [35] & 406 & $\begin{array}{l}\text { prospective } \\
\mathrm{T} 1-4, \mathrm{pN} 0-2\end{array}$ & 5.7 & 4.4 & 1.5 & $\begin{array}{l}\text { staging is needed in high risk } \\
\text { groups ( } \mathrm{T} 4 \mathrm{~N}>4+\text { ) only }\end{array}$ \\
\hline Lee, 2005 [36] & 1,939 & $\begin{array}{l}\text { retrospective } \\
\text { stage I-III } \\
\text { stage I } \\
\text { stage IIA } \\
\text { stage IIB } \\
\text { stage IIIA } \\
\text { stage IIIB } \\
\text { stage IIIC }\end{array}$ & $\begin{array}{r}1.4 \\
0.7 \\
0.6 \\
0.6 \\
4.0 \\
16.7 \\
4.4\end{array}$ & 0.2 & 0.7 & $\begin{array}{l}\text { bone scan is of little value in } \\
\text { stage I-II, but highly } \\
\text { recommended in stage III } \\
\text { or higher }\end{array}$ \\
\hline Ciatto, 1985 [37] & 1,017 & $\begin{array}{l}\text { prospective } \\
\text { stage I-II } \\
\text { stage III }\end{array}$ & $\begin{array}{l}0.26 \\
2.77\end{array}$ & $\begin{array}{l}0.59 \text { (overall } \\
\text { detection } \\
\text { rate) }\end{array}$ & $\begin{array}{l}0.29 \text { (overall } \\
\text { detection } \\
\text { rate) }\end{array}$ & no routine perioperative staging \\
\hline
\end{tabular}

${ }^{\mathrm{a} A J C C}$ stage.

widely available. X-ray is an established method in the detection of pulmonary and bone metastases, it is cheap and always available. The aim of the presented literature review is the evaluation of X-ray in the detection of pulmonary and bone metastases in patients without signs of distant tumor spread (cM0) at the time of primary treatment (perioperative staging) and during follow-up of asymptomatic BC survivors, and its role in the further diagnosis of suspicious hot spots in bone scans (BS).

\section{Materials and Methods}

PubMed was searched for articles (clinical trials, meta-analyses, randomized controlled trials, and reviews) which studied the impact of BS and X- ray in the detection rate of metastases in symptomatic and asymptomatic $\mathrm{BC}$ patients, perioperatively and during normal follow-up.

Key words used for the search were: bone scan, chest X-ray (CXR), Xray, metastasis, detection rate, breast cancer follow-up, breast cancer, breast, recurrence, hot spot. In total, 173 abstracts were examined in MEDLINE. From these, 27 abstracts and 1 Cochrane database system review thoroughly met the objective. These articles were obtained and reviewed.

\section{Results}

\section{Perioperative Screening}

With regard to perioperative staging examinations, several studies have conformingly shown that there is no general advantage for low risk $\mathrm{BC}$ patients in the detection of distant 
Table 2. Regular chest X-ray during follow-up in asymptomatic breast cancer survivors

\begin{tabular}{|c|c|c|c|c|c|c|c|}
\hline Author, year & $\begin{array}{l}\text { Patients, } \\
\mathrm{n}\end{array}$ & Patient characteristics & $\begin{array}{l}\text { Asymptomatic } \\
\text { metastases }\end{array}$ & $\begin{array}{l}\text { False } \\
\text { positive } \\
\text { results }\end{array}$ & DFS & OAS & Conclusion \\
\hline $\begin{array}{l}\text { Hurria et al., } 2003 \\
\text { [15] }\end{array}$ & 533 & $\begin{array}{l}\text { retrospective, stage I-II } \\
\text { breast cancer }\end{array}$ & $0.8 \%$ & $90 \%$ & - & - & $\begin{array}{l}\text { chest imaging is } \\
\text { of limited value in } \\
\text { asymptomatic patients }\end{array}$ \\
\hline $\begin{array}{l}\text { Imoto and Jitsuiki, } \\
1998 \text { [18] }\end{array}$ & 550 & retrospective, stage I-III & $1.5 \%$ & - & - & no benefit & $\begin{array}{l}\text { intensive follow-up } \\
\text { should be limited to } \\
\text { high-risk patients only }\end{array}$ \\
\hline Pivot et al., 2000 [13] & 1125 & $\begin{array}{l}\text { prospective, } \mathrm{p} 1-4 \mathrm{pN} 0 /+ \\
\text { cM0 }\end{array}$ & $10.3 \%$ & - & no benefit & no benefit & $\begin{array}{l}\text { reduce follow-up to } \\
\text { careful history }\end{array}$ \\
\hline Yeh et al., 1995 [16] & 316 & $\begin{array}{l}\text { retrospective, pT1-2 pN0/+ } \\
\text { cM0 }\end{array}$ & $2 \%$ & $89.0 \%$ & - & - & $\begin{array}{l}\text { high false positive } \\
\text { rate. }\end{array}$ \\
\hline $\begin{array}{l}\text { Rosselli Del Turco } \\
\text { et al., } 1994 \text { [14] }\end{array}$ & 1243 & $\begin{array}{l}\text { randomized, pT1-4 pN0/+ } \\
\text { cM0, intensive vs. clinical } \\
\text { group }\end{array}$ & 9.0 vs. $5.7 \%$ & - & $\begin{array}{l}\text { benefit in } \\
\text { clinical } \\
\text { group }\end{array}$ & no benefit & $\begin{array}{l}\text { diagnostic tests only } \\
\text { in the presence of } \\
\text { symptoms }\end{array}$ \\
\hline GIVIO, 1994 [17] & 1320 & $\begin{array}{l}\text { prospective, } \mathrm{T} 1-3, \mathrm{~N} 0-1, \\
\mathrm{cM} 0, \text { intensive vs. clinical } \\
\text { group }\end{array}$ & $\begin{array}{l}31 \text { and } 21 \% \text { of } \\
\text { primarily detected } \\
\text { metastases }\end{array}$ & - & no benefit & no benefit & $\begin{array}{l}\text { routine use of } \\
\text { intensive follow-up } \\
\text { should be discouraged }\end{array}$ \\
\hline $\begin{array}{l}\text { Joseph et al., } 1998 \\
\text { [12] }\end{array}$ & 1898 & $\begin{array}{l}\text { retrospective, pT1-4 pN0/+ } \\
\text { cM0, intensive vs. PE } \\
\text { group }\end{array}$ & $\begin{array}{l}6.8 \% \text { overall } \\
\text { metastases: } \\
21 \text { vs. } 79 \%\end{array}$ & - & - & no benefit & $\begin{array}{l}\text { diagnostic tests only } \\
\text { in symptomatic } \\
\text { patients }\end{array}$ \\
\hline
\end{tabular}

DFS = Disease-free survival; OAS = overall survival.

metastasis, as well as for disease free survival (DFS) and OAS (table 1). This is also true for the detection of pulmonary or bone metastases by CXR. Dillman et al. [3] have shown a distant metastases rate in stage I BC patients of $0.4 \%$, in stage IIa of $1.2 \%$, and in stage IIb of $6.8 \%$, and recommend staging only in high risk patients with tumors greater than pT3 or with positive lymph node involvement. For the BC stages, the TNM system and the definition of the American Joint Committee on Cancer (AJCC) were used [4]. A different definition of high risk patients has been established by Ravaioli et al. [5]. According to them, BC patients can be divided into 2 different risk groups: a low risk group containing pT1-3 patients with up to 3 involved lymph nodes, and a high risk group including all patients with more than 3 involved lymph nodes, pT4, and pN2 tumors. Other studies like Myers et al. [6], Puglisi et al. [7], and Samant et al. [8] defined similar groups of high and low risk BC patients. Perioperative detection rates for pulmonary and bone metastases are very low in low risk $\mathrm{BC}$ patients and are incommensurate with the high costs of staging examinations $[9,10]$. In addition to high rate of false positive findings and missing therapeutic consequences, perioperative staging examinations let the patients feel even more insecure and decrease their health-related quality of life [11]. Most authors (table 1) recommended perioperative screening in high risk patients only. However, even in these patients, there is no apparent advantage in the early detection of occult metastases. The only reason for screening these patients is the avoidance of aggressive adjuvant treatment in cases of distant metastases [11]. It is not adequate to define risk profile by tumor size and number of involved lymph nodes. The individual risk is better defined by biological characteristics like endocrine responsiveness, HER2 expression, and epidermal growth factor receptor (EGFR).

\section{Chest X-Ray during Follow-Up of BC Patients}

Most studies concerned with regular CXR in follow-up of asymptomatic BC patients were published years ago (table 2). All major studies have shown an insignificant detection rate of distant metastasis and no benefit for OAS [12-14]. Again, CXR screening is associated with little clinical value, high false positive rates, and high costs $[15,16]$. Early detection simply increases the period during which a metastasis is observed and does not add a survival advantage in asymptomatic patients $[12-14,17,18]$. Any treatment option in the situation of asymptomatic metastasis results in a decrease of quality of life. Offering CXR only to symptomatic patients during follow-up, makes a significant difference in the time to detection of metastasis in asymptomatic patients without enlarging the risk of increased OAS [14]. Especially in asymptomatic patients, early detection of metastases would initiate treatment and can easily lead to overtreatment. Up to now, there is no evidence that early detection of advanced disease and imme- 
Table 3. Chest X-ray in symptomatic breast cancer survivors and influence on outcome

\begin{tabular}{|c|c|c|c|c|c|c|c|}
\hline Author, year & $\begin{array}{l}\text { Patients, } \\
\mathrm{n}\end{array}$ & Patient characteristics & Detection rate, \% & $\begin{array}{l}\text { False posi- } \\
\text { tive rate, \% }\end{array}$ & DFS & OAS & Conclusion \\
\hline Pivot, 2000 [13] & 1,125 & $\begin{array}{l}\text { randomized } \\
\text { pT1-4 pN0/+ cM0 }\end{array}$ & 10.3 (by imaging) & - & no benefit & no benefit & $\begin{array}{l}\text { no routine CXR } \\
\text { for follow-up }\end{array}$ \\
\hline Kokko, 2003 [27] & 472 & $\begin{array}{l}\text { randomized } \\
\text { pT1-4 pN0/+ cM0 } \\
\text { regular CXR vs. clinically }\end{array}$ & 3.7 vs. 3.5 & 80 vs. 78 & no benefit & no benefit & $\begin{array}{l}\text { no routine CXR } \\
\text { for follow-up }\end{array}$ \\
\hline Ciatto, 1983 [26] & 1,697 & $\begin{array}{l}\text { retrospective } \\
\text { symptomatic vs. } \\
\text { asymptomatic }\end{array}$ & 39 vs. 7 & & no benefit & $\begin{array}{l}\text { no benefit } \\
\text { for follow-up }\end{array}$ & no routine $\mathrm{CXR}$ \\
\hline
\end{tabular}

DFS = Disease-free survival; OAS = overall survival; CXR = chest X-ray.

Table 4. Chest X-ray for further evaluation of hot spot in bone scan in breast cancer survivors $\mathrm{pT} 1-4 \mathrm{pN} 0 /+\mathrm{cM} 0$

\begin{tabular}{|c|c|c|c|c|}
\hline Author, year & $\begin{array}{l}\text { Patients, } \\
\mathrm{n}\end{array}$ & Patient characteristics & Detection rate, \% & Conclusion \\
\hline Kara, 2003 [28] & 75 & $\begin{array}{l}\text { retrospective } \\
1 \text { solitary hot spot on a bone scan }\end{array}$ & $\begin{array}{l}26.1 \text { (bone metastases); } 73.1 \text { (benign } \\
\text { origin); } 0.8 \text { (unclear etiology) }\end{array}$ & $\begin{array}{l}\text { solitary rib lesions on } \\
\text { bone scans are frequently } \\
\text { of benign origin }\end{array}$ \\
\hline Chen, 2003 [33] & 115 & $\begin{array}{l}\text { retrospective } \\
1 \text { hot spot } \\
2 \text { hot spots } \\
1 \text { hot spot }+ \text { concurrent bone abnormality }\end{array}$ & $\begin{array}{l}14.3 \\
11.1 \\
81.8\end{array}$ & $\begin{array}{l}\text { regular follow-up for } \\
2 \text { years after detection of rib } \\
\text { lesions is recommended }\end{array}$ \\
\hline Wups, 2002 [29] & 199 & $\begin{array}{l}\text { retrospective } \\
\text { solitary rib hot spots }\end{array}$ & $\begin{array}{l}11.8 \text { (bone metastases, } 9.1 \text { with pain); } \\
88.2 \text { (benign origin) }\end{array}$ & $\begin{array}{l}\text { further radiodiagnostics are } \\
\text { needed for clarification }\end{array}$ \\
\hline Jacobson, 1990 [31] & 301 & $\begin{array}{l}\text { retrospective } \\
1 \text { hot spot (asymptomatic patients) } \\
2 \text { hot spots (asymptomatic patients) }\end{array}$ & $\begin{array}{l}11 \\
24\end{array}$ & $\begin{array}{l}\text { most solitary rib hot spots } \\
\text { are benign }\end{array}$ \\
\hline Koizumi, 2003 [38] & 5,538 & $\begin{array}{l}\text { retrospective } \\
\text { solitary or multiple lesions }\end{array}$ & $\begin{array}{l}12.7 \text { (overall detection rate); } \\
41 \text { (solitary metastases); } \\
59 \text { (multiple metastases) }\end{array}$ & $\begin{array}{l}\text { solitary hot spots are inde- } \\
\text { pendent prognostic factors }\end{array}$ \\
\hline Baxter, 1995 [32] & 34 & $\begin{array}{l}\text { retrospective } \\
\quad \text { reliability of bone scan interpretation }\end{array}$ & $\begin{array}{l}41 \text { (malignant); } 35 \text { (benign); } \\
24 \text { (indeterminate) }\end{array}$ & $\begin{array}{l}\text { further radiodiagnostics are } \\
\text { needed for clarification }\end{array}$ \\
\hline Jacobson, 1990 [31] & 183 & $\begin{array}{l}\text { retrospective } \\
\text { reliability of bone scan interpretation }\end{array}$ & 9.3 (malignant) & $\begin{array}{l}\text { further radiodiagnostics are } \\
\text { needed for clarification }\end{array}$ \\
\hline Tumeh, 1985 [39] & 2,851 & $\begin{array}{l}\text { retrospective } \\
1 \text { hot spot }\end{array}$ & $\begin{array}{l}9.8 \text { (solitary malignant); } \\
53.2 \text { (benign fractures); } \\
27 \text { (associated with postoperative } \\
\text { radiation therapy) }\end{array}$ & $\begin{array}{l}\text { solitary rib lesions are most } \\
\text { frequently associated with a } \\
\text { benign etiology }\end{array}$ \\
\hline
\end{tabular}

diate treatment would improve OAS. To the knowledge of the authors, there are no ongoing or planned studies dealing with this question. Not only overtreatment but also the simple knowledge of metastases in asymptomatic patients can result in decreased health-related quality of life. On the other hand, there is a high demand on follow-up in BC patients. Especially young women with sometimes more aggressive tumors are not willing to reduce the frequency of follow-up visits in order to be reassured about their health status. Good strategies of sharing information between patient and doctor might help women to be equally reassured when less follow-up is offered and might resolve this conflict. Regular physical examinations and yearly mammography alone are as effective as more intensive approaches based on laboratory tests and instrumental 
tests [19]. As a result, less intensive follow-up strategies based on periodical clinical examinations seem as efficient as more intense surveillance schemes in low risk asymptomatic patients. High false positive rates and lacking therapeutically options are also limitations to intensive follow-up in this patient group. According to literature reviews, a regular follow-up could only be recommended in high risk patients. However, all guidelines [20-23] do not recommend regular diagnostic follow-up particularly in this high risk group. So far, there are no data showing any OAS benefit of early treatment in clinically asymptomatic patients. A study published by John et al. [24] even indicates an increased risk of BC, particularly in genetically susceptible women, who underwent some form of lowdose radiation like CXR. Taking this into consideration, CXR should be used even more restrictedly. Reduced follow-up strategies for $\mathrm{BC}$ can improve quality of life by reducing the anxiety experienced at each follow-up visit [25].

\section{Chest X-Ray in Symptomatic BC Patients}

Regarding the observations of John et al. [24], one has to also review the usefulness and frequency of CXR in symptomatic patients. The detection rate in symptomatic patients is generally higher than in asymptomatic patients but has no influence on DFS and OAS (table 3) [13, 26]. Whether recurrence was found at the scheduled follow-up visits or between scheduled visits, symptoms were the primary indicator of relapse. Within this symptomatic group, Pivot et al. [13] detected only $10.3 \%$ metastases by CXR, indicating a low importance of CXR in symptomatic patients. Approximately 3 times more CXR have to be taken to detect metastases in asymptomatic patients. In addition, it is associated with a high false positive rate [27]. Patients in whom relapse has been falsely suspected are likely to suffer anxiety and derive harm rather than benefit from the $\mathrm{X}$-ray examination.

\section{Chest X-Ray for Further Evaluation of Hot Spots in BC Survivors}

BS is accepted as a very sensitive method for the investigation of skeletal metastases, and, despite rapid advances in all imaging modalities, there has been no serious challenge to BS for the detection of skeletal metastasis. Nevertheless, BS should only be considered in symptomatic patients. Table 4 reviews the studies dealing with further evaluation of hot spots in BS. For further evaluation of pathological findings in BS, CXR is still an established procedure. The detection of solitary rib lesion either during perioperative staging or follow-up examinations in $\mathrm{BC}$ patients is not uncommon and presents a major diagnostic problem. Single hot spots in a BS are frequently of benign origin and cause a lot of unnecessary radiographic tests and expenses for the health system [16, 28, 29].The more abnormalities occur in BS, the higher the risk of metastasis [30]. In asymptomatic patients with 1 or 2 abnormalities, most benign changes either remain unchanged or resolve within 12-24 month [31]. For further clarification of these mostly benign hot spots, additional CXR and other radiological tests are necessary [31, 32]. In cancer patients with 1 or 2 new BS abnormalities, correlative radiographs showing a benign abnormality are reliable [31]. Chen et al. [33] showed that direct tumor invasion to the chest wall or skin, 10 or more involved lymph nodes, and no radiotherapy were associated with increased risk of bone metastases whereas a longer time interval between surgery and rib lesion detection and longer persistence of the rib lesions were associated with lower risk of distant metastasis.

\section{Conclusion}

With the evidence presented in the synopsis above and the reviewed literature, the following conclusions can be drawn. For low risk BC patients, perioperative X-ray is not indicated. This also applies to routine X-ray and other radiological tests during follow-up in asymptomatic patients, due to no benefit in DFS, OAS, and high costs. A high number of false positive findings with further diagnostic procedures impair the quality of life. Hot spots in BS have to be carefully evaluated. In most cases, they are of benign cause, and the validity of these findings has to be assessed carefully. Due to lacking therapeutic potential, early detection is only valuable if more effective treatment modalities are available, and randomized clinical trials have shown their superiority in asymptomatic detected metastases compared to symptomatic patients.

\section{References}

1 Nicolini A, Tartarelli G, Carpi A, et al.: Intensive post-operative follow-up of breast cancer patients with tumour markers: CEA, TPA or CA15.3 vs. MCA and MCA-CA15.3 vs. CEA-TPA-CA15.3 panel in the early detection of distant metastases. BMC Cancer 2006;6:269.

2 Perrone MA, Musolino A, Michiara M, et al.: Early detection of recurrences in the follow-up of primary breast cancer in an asymptomatic or symptomatic phase. Tumori 2004;90:276-9.

$\checkmark 3$ Dillman RO, Chico S: Radiologic tests after a new diagnosis of breast cancer. Eff Clin Pract 2000;3: $1-6$.
4 Singletary SE, Allred C, Ashley P, et al.: Revision of the American Joint Committee on Cancer staging system for breast cancer. J Clin Oncol 2002;20: 3628-36.

5 Ravaioli A, Pasini G, Polselli A, et al.: Staging of breast cancer: new recommended standard procedure. Breast Cancer Res Treat 2002;72:53-60.

6 Myers RE, et al.: Baseline staging tests in primary breast cancer: a practice guideline. CMAJ 2001;164: 1439-44.

7 Puglisi F, Follador A, Minisini AM, et al.: Baseline staging tests after a new diagnosis of breast cancer: further evidence of their limited indications. Ann Oncol 2005;16:263-6.
8 Samant R, Ganguly P: Staging investigations in patients with breast cancer: the role of bone scans and liver imaging. Arch Surg 1999;134:551-3; discussion 554.

9 Hannisdal E, Gundersen S, Kvaløy S, et al.: Followup of breast cancer patients stage I-II: a baseline strategy. Eur J Cancer 1993;29A:992-7.

10 Norum J, Andreassen T: Screening for metastatic disease in newly diagnosed breast cancer patients. What is cost-effective? Anticancer Res 2000;20: 2193-6. 
11 Gerber B, Seitz E, Müller H, et al.: Perioperative screening for metastatic disease is not indicated in patients with primary breast cancer and no clinical signs of tumor spread. Breast Cancer Res Treat 2003;82:29-37.

12 Joseph E, Hyacinthe M, Lyman GH, et al.: Evaluation of an intensive strategy for follow-up and surveillance of primary breast cancer. Ann Surg Oncol 1998;5:522-8.

13 Pivot X, Asmar L, Hortobagyi GN, et al.: A retrospective study of first indicators of breast cancer recurrence. Oncology 2000;58:185-90.

14 Rosselli Del Turco M, Palli D, Cariddi A, et al.: Intensive diagnostic follow-up after treatment of primary breast cancer. A randomized trial. National Research Council Project on Breast Cancer followup. JAMA 1994;271:1593-7.

15 Hurria A, Leung D, Trainor K, et al.: Screening chest imaging studies are not effective in the follow-up of breast cancer patients. J Oncol Manag 2003;12:13-5.

16 Yeh KA, Fortunato L, Ridge JA, et al.: Routine bone scanning in patients with $\mathrm{T} 1$ and $\mathrm{T} 2$ breast cancer: a waste of money. Ann Surg Oncol 1995;2: 319-24.

17 No authors listed: Impact of follow-up testing on survival and health-related quality of life in breast cancer patients. A multicenter randomized controlled trial. The GIVIO Investigators. JAMA 1994; 271:1587-92.

18 Imoto S, Jitsuiki Y: Detection of the first recurrence during intensive follow-up of breast cancer patients. Jpn J Clin Oncol 1998;28:597-600.

19 Rojas MP, Telaro E, Russo A, et al.: Follow-up strategies for women treated for early breast cancer. Cochrane Database Syst Rev 2005;1:CD 001768.

20 Arbeitsgemeinschaft Gynäkologische Onkologie: A., Leitlinien Gynäkologische Onkologie 2007, Komission Mamma. www.ago-online.org/index php? site=mamma_guide \&lang $=$ de .

21 ASCO, American Society of Clinical Oncology: 2006 Update of the Breast Cancer Follow-up and Management Guideline in the Adjuvant Setting. www.asco.org/portal/site/ASCO/menuitem.509189bf d2c2bf5ca7ffa807320041a0/?vgnextoid $=6 f 8 f 27 f 0608$ 2a010VgnVCM100000ed730ad1RCRD.

22 Deutsche Gesellschaft für Gynäkologie und Geburtshilfe: Diagnostik, Therapie und Nachsorge des Mammakarzinoms der Frau (S3) Interdisziplinäre Leitlinie der Deutschen Krebsgesellschaft (DKG) und derbeteiligten medizinisch-wissenschaftlichen Fachgesellschaften, 2004. www.alt.dggg.de/leitlinien2006/index.html.

23 NCCN: NCCN Clinical Practice Guidelines in Oncology $^{\mathrm{TM}}$, 2007. www.nccn.org/professionals/physician_gls/f_guidelines.asp? button=I+Agree\#site.

24 John EM, Phipps AI, Knight JA, et al.: Medical radiation exposure and breast cancer risk: findings from the Breast Cancer Family Registry. Int J Cancer 2007;121:386-94.
25 Kimman ML, Voogd AC, Dirksen CD, et al.: Follow-up after curative treatment for breast cancer: why do we still adhere to frequent outpatient clinic visits? Eur J Cancer 2007;43:647-53.

26 Ciatto S, Herd-Smith A: The role of chest X-ray in the follow-up of primary breast cancer. Tumori 1983;69:151-4.

27 Kokko R, Hakama M, Holli K: Role of chest X-ray in diagnosis of the first breast cancer relapse: a randomized trial. Breast Cancer Res Treat 2003;81: 33-9.

28 Kara G, Bozkurt MF, Ozcan PP, et al.: Solitary rib lesions in bone scans of patients with breast carcinoma. Nucl Med Commun 2003;24:887-92.

29 Wu PS, Chiu NT, Lee BF, et al.: Clinical significance of solitary rib hot spots on bone scans in patients with extraskeletal cancer: correlation with other clinical manifestations. Clin Nucl Med 2002; 27:567-71.

30 Jacobson AF, Stomper PC, Jochelson MS, et al.: Association between number and sites of new bone scan abnormalities and presence of skeletal metastases in patients with breast cancer. J Nucl Med 1990;31:387-92.

31 Jacobson AF, Cronin EB, Stomper PC, Kaplan WD: Bone scans with one or two new abnormalities in cancer patients with no known metastases: frequency and serial scintigraphic behavior of benign and malignant lesions. Radiology 1990;175: 229-32.

32 Baxter AD, Coakley FV, Finlay DB, et al.: The aetiology of solitary hot spots in the ribs on planar bone scans. Nucl Med Commun 1995;16:834-7.

33 Chen HH, et al.: Clinical significance and outcome of one or two rib lesions on bone scans in breast cancer patients without known metastases. Nucl Med Commun 2003;24:1167-74.

34 Abuzallouf S, Motawy M, Thotathil Z: Baseline staging of newly diagnosed breast cancer - Kuwait cancer control center experience. Med Princ Pract 2007;16:22-4

35 Ravaioli A, Tassinari D, Pasini G, et al.: Staging of breast cancer: what standards should be used in research and clinical practice? Ann Oncol 1998;9: 1173-7.

36 Lee JE, Park SS, Han W, et al.: The clinical use of staging bone scan in patients with breast carcinoma: reevaluation by the 2003 American Joint Committee on Cancer staging system. Cancer 2005;104: 499-503.

37 Ciatto S, Pacini P, Bravetti P, et al.: Staging breast cancer - screening for occult metastases. Tumori 1985;71:339-44.

38 Koizumi M, Yoshimoto M, Kasumi F, et al.: Comparison between solitary and multiple skeletal metastatic lesions of breast cancer patients. Ann Oncol 2003;14:1234-40.

39 Tumeh SS, Beadle G, Kaplan WD: Clinical significance of solitary rib lesions in patients with extraskeletal malignancy. J Nucl Med 1985;26:1140-3. 